\title{
RISK CATEGORISATION OF PRODUCTS USED FOR THE CONSTRUCTION OF ELECTRICITY DISTRIBUTION ASSETS
}

\author{
A.J. le Roux ${ }^{1}$ and C.C. van Waveren ${ }^{2}$ \\ ${ }^{1,2}$ Graduate School of Technology Management \\ University of Pretoria, South Africa \\ corro@up.ac.za
}

\begin{abstract}
The balance between risk and reward is the very essence of business, and companies take risks in order to generate returns. Eskom, the electricity utility in South Africa, endeavors to construct networks that are reliable and safe for its employees as well as the public. To ensure that product reliability requirements align with company goals, products should be categorised according to the risk they pose to the business. Mitigating strategies can therefore be reviewed for high risk items. A $3 \times 3$ risk matrix was derived to identify the risk category for products. The application of the process should result in an improvement in product profitability, either directly through a reduction in purchasing cost, or indirectly through avoiding the various consequential costs associated with poor risk management.
\end{abstract}

\begin{abstract}
Om 'n balans te bereik tussen risiko en vergoeding vorm deel van die dinamiese bestaan van sakeondernemings wat risiko's moet loop om opbrengste te genereer. Eskom, die voorsiener van elektrisiteit in Suid Afrika, poog om netwerke op te rig. Terplaatse produkte wat hiervoor aangewend word en die betroubaarheidsdoelwitte eerbiedig, moet gekategoriseer word teen die tafereel van ondernemingsrisiko. 'n Risikomatriks wat versagtende strategieë voorhou, word daarvoor aangewend. Die gebruik van die metode poog om die winsgewendheid van die onderneming te verbeter teen die agtergrond van verkrygingskoste en die gevolglike koste van swak risikobestuur.
\end{abstract}

\footnotetext{
${ }^{1}$ The author was enrolled for an M Eng (Engineering Management) in the Department of Engineering and Technology Management, University of Pretoria.
} 


\section{INTRODUCTION}

Over the last 80 years Eskom has established itself as a world leader in electricity provision, supplying over 95\% of South Africa's electricity needs and over $50 \%$ of the electricity needs on the African continent. During this time, it has demonstrated an ability to provide the world's lowest cost electricity to its customers while making superior technological innovations, bringing increased reliability to the transmission system. Current demand for electricity, forced Eskom to revise its strategy and to plan for increasing supply, manage demand and optimise its structures. The distribution part of Eskom is in the process of being unbundled into six independent Regional Electricity Distributors (REDs). The separation of operations influences several systems, processes and procedures currently common to distribution. One such process is the supply chain for products to construct network infrastructure such as substations, lines, and electrification. A sub-process of the supply chain is the establishment of an approved product list with multiple manufacturers per product.

\subsection{Weakness of the current supply chain}

Network failures experienced by Eskom's Distribution Division are due to three main factors:

- $\quad$ Quality of material (products not meeting specifications)

- $\quad$ Quality of workmanship (poor or incorrect techniques applied)

- $\quad$ Natural occurrences (severe weather conditions, etc.)

The material problem relates directly to the supply chain. Owing to government regulation, Eskom purchases products from a multiplicity of manufacturers. Because of this open market policy, around 5,523 product manufacturers are used.

The current supply chain principles do not take into account the function of the product or the consequences if a failure occurs. Purchasing is purely based on specifications and the lowest tendered price, in conjunction with Eskom's black empowerment policies.

Many of the products used are low cost items and are manufactured in high volumes. The consequences of their failure might, however, be catastrophic - for example:

- $\quad$ Fatalities or injuries (human \& animal)

- $\quad$ Loss of revenue/supply

- $\quad$ Safety hazard

- Impact on Key Performance Indicators

- $\quad$ Negative image of Eskom

- $\quad$ Cost of overtime

\subsection{Reason for risk categorisation of products}

Eskom endeavours to construct networks that are reliable and safe for its employees as well as the public. The reliability of a network is directly proportional to the 
reliability of the products used.

To ensure that product reliability requirements align with company goals, products should be categorised according to the risk they pose to the business. Mitigating strategies can therefore be reviewed for high risk items. This will ensure that reliability and durability are designed into the products via stricter standards and quality system requirements that align with manufacturing complexity. The objective of the study was to apply risk management principles, and to propose an effective model of product risk categorisation that can consistently be applied by technical persons to acquire safe and reliable products.

\section{DEFINITION OF RISK AND RISK MANAGEMENT}

In a world of increasing complexity and uncertainty, companies must manage risk more rigorously than ever. According to Reuvid 0 it is an essential aspect of good corporate governance. One key distinction between risk management in general and technical risk management is the reduced dependence of the latter on insurance as a risk mitigation measure. Technical risk management is therefore a function of controlling hazards and risks of a technical nature.

\subsection{Definition of risk}

To understand the concept of risk management, the concept of risk must be defined. According to Engert and Lansdowne [2]: "Risk is a measure of a project's inability to achieve system life cycle objectives. It comprises two components: the probability of failing to achieve particular system life cycle objectives, and the consequences of failing to achieve those objectives."

According to Smith [3], risk can be defined generically as a measure of the likelihood and consequence of a particular occurrence. He defined product component risk as a measure of the potential for a particular component to have a negative impact upon the end product, system, or sub-system.

\subsection{Definition of risk management}

According to Engert and Lansdowne [2], "Risk management is the act or practice of controlling risk. This process includes identifying and tracking risk areas, developing risk mitigation plans as part of risk handling, monitoring risks and performing risk assessments to determine how risks have changed."

\subsection{Product risk management}

For the purpose of this paper, the objective of product risk management is to present practical information to supply chain managers so that they understand the different types of product component risks. A methodology must be derived for quantifying, tracking, reducing, or containing each type of risk, and suggesting tools for implementing the risk management process. 


\section{THE RISK MANAGEMENT PROCESS}

Various approaches to the process of risk management have been identified in the literature. Most of the processes complement each other. For example, the approach of the Australian Capital Territory Insurance Authority (ACTIA) [4] is to use Risk Management Standards (AS/NZS 4360:2004) as a basis for a risk management process. The research was extended with contributions from other literature. The process follows the following steps:

1. Establishing goals and context (the risk environment): The first step in the risk management process is to establish the environment and the goals for the environment. It is against these goals that the risk assessment is undertaken. According to National Minerals Industry [5], the success of a risk assessment exercise is mainly determined by the integrity of its fundamental design, sometimes called the 'scope'.

2. Identifying risks: Risk identification is "the process of determining what can happen, why and how [4]". The quality of a risk assessment greatly depends on identifying and understanding the hazards and unwanted events, and assessing the specific risks. The purpose of this stage is to identify the risks that are likely to affect the achievement of the goals of the established environment.

3. Analyzing the identified risks: This step in the risk assessment process requires that, for each risk, the current controls and their effectiveness must be identified. The risk level must also be established by using a risk matrix that is specific to the company.

4. Evaluating the risks: This step of the risk assessment process requires one to assess the level of risk that is acceptable (risk is sufficiently low, and treatment is not considered cost-effective) or unacceptable (risk requires treatment). The categorisation of the risk according to the risk rating should guide this decision.

5. Treating the risks: The objective of this stage of the risk assessment process is to develop cost-effective options for treating the risks. Treatment options are driven by outcomes that include avoiding, reducing, transferring, or retaining the risk.

6. Monitoring the risk environment regularly: Risks and their priorities do not remain constant. Risk needs to be regularly monitored, and new risks and their impact need to be included in the risk management plan of the business.

7. Continuously communicating: Channels must be established in the business to communicate areas of high risk to internal and external stakeholders. Processes must also be implemented that will escalate risks from the field to the risk coordinator. This will ensure that the risk categorisation criteria are revised on a regular basis to portray the real risks.

\section{DEVELOPING A RISK CATEGORISATION MODEL}

A risk matrix specific to Eskom was derived following the risk management process of ACTIA [4]. 


\subsection{Establish goals context (The risk environment)}

The environment: The business environment is Eskom. All the goals, strategic intent, and business principles therefore apply. Secondary environments are product manufacturing processes, plant, and equipment, as well as the physical environments where the products are installed.

Goals for the environment: These are Eskom's goals. A set of goals for the environment are implied in the Eskom Distribution Strategic intent: "Eskom Distribution will lead in the provision of electricity services and customer satisfaction through empowered, sustainable regional businesses, for the benefit of our country."

Manufacturing goals: Typical goals for the manufacturing plant include the optimal use of resources, maximizing material usage, consistently manufacturing a quality product, and meeting product specifications.

Customer goals: Customer goals include reliability of supply, safety, and an affordable product.

Summary of key goals for the environment: The following key goals were identified from different environments:

- $\quad$ Safety (Ensure safety to public and personnel)

- $\quad$ Reliability (Continuity of supply)

- $\quad$ Benefit to industry

- Customer satisfaction

- Operational efficiency and effectiveness

- $\quad$ Profitable company but affordable product

- $\quad$ Sustainability (Profit through the sale of electricity)

- $\quad$ Corporate image sustainability

- $\quad$ Financial viability

- $\quad$ Continuous improvement

- $\quad$ Research and development

The goals were grouped and rated by a technical and management panel. The three most important goals that were used for the impact assessment were safety, customer satisfaction, and financial viability.

\subsection{Identifying the risks}

For the purpose of identifying the risks, only risks associated with the products to be used for the construction of Eskom networks were identified. Four risk areas were identified:

1. Design risk: The risk associated with incorrect decisions - e.g. incorrect tolerances, incorrect specification.

2. Manufacturing risk: The risk associated with a product that does not meet the specification. 
3. Installation risk: The risk associated when a product is not installed according to specification.

4. Maintenance risk: The risk associated with a lack of maintenance or incorrect maintenance procedure.

\subsection{The risk consequence}

Section 3 highlights the need for a company-specific risk matrix for the purposes of risk analysis. As there was no risk matrix for Eskom products, one was developed. For simplicity and ease of use, three levels of impact or consequence - minor, moderate, and major - were chosen. The risks in relation to safety, customer satisfaction, and financial consequences were then rated.

1. Safety consequence: Safety relates to the impact on the public as well as Eskom personnel. Table 1 depicts typical safety criteria as well as the risk rating for each criterion. The final consequence can be categorised as indicated in Table 2, by adding the scores from Table 3.

2. Customer satisfaction consequence: Customer satisfaction is directly related to the availability of supply. The influence on the number of customers affected by a product failure is therefore related to customer satisfaction. Customer satisfaction can therefore be rated as shown in Table 3.

3. Financial consequence: Financial impact takes into account costs related to outages to remedy a fault, replacement of the faulty product, loss in revenue due to lack of sales, and legal consequences. The risk was quantified as a percentage of the profit of one region. There are, however, different views about this categorisation, and different options will have to be investigated after the formation of Regional Electricity Distributors (REDs), taking into account the financial viability of each RED. The financial consequence is given in Table 4.

\begin{tabular}{|c|c|c|c|}
\hline \multirow{2}{*}{ Criteria } & \multicolumn{3}{|c|}{ Rating } \\
\hline & 1 & 2 & 3 \\
\hline $\begin{array}{l}\text { Population density where } \\
\text { product is used? }\end{array}$ & $\begin{array}{l}\text { Unpopulated } \\
\text { rural }\end{array}$ & $\begin{array}{l}\text { Unpopulated } \\
\text { and populated } \\
\text { rural }\end{array}$ & $\begin{array}{l}\text { Populated } \\
\text { rural }\end{array}$ \\
\hline $\begin{array}{l}\text { Will live conductors be in } \\
\text { close proximity to people } \\
\text { if products fail? }\end{array}$ & No & & Yes \\
\hline $\begin{array}{l}\text { Do protection systems } \\
\text { exist to prevent or reduce } \\
\text { dangerous situations? }\end{array}$ & $\begin{array}{l}\text { Protection will } \\
\text { always } \\
\text { neutralize the } \\
\text { failure }\end{array}$ & $\begin{array}{l}\text { Protection will } \\
\text { sometimes } \\
\text { neutralize the } \\
\text { failure }\end{array}$ & $\begin{array}{c}\text { Protection } \\
\text { will seldom } \\
\text { neutralize } \\
\text { the failure }\end{array}$ \\
\hline $\begin{array}{c}\text { Seriousness of possible } \\
\text { injuries }\end{array}$ & Minor & Serious & Death \\
\hline Treatment of injuries & First aid & Hospitalization & $\begin{array}{l}\text { Death (no } \\
\text { treatment) }\end{array}$ \\
\hline $\begin{array}{c}\text { Are there any road } \\
\text { crossings? }\end{array}$ & & & Yes \\
\hline
\end{tabular}

Table 1: Impact or consequence related to safety 


\begin{tabular}{|c|c|c|}
\hline Minor & Moderate & Major \\
\hline 5 & 10 & 15 \\
\hline Minor & Moderate & Major \\
\hline $\begin{array}{l}\text { Some customers } \\
\text { disconnected, } \\
\text { localized in a small } \\
\text { geographic area with } \\
\text { fewer than } 100 \\
\text { customers }\end{array}$ & $\begin{array}{l}\text { Dissatisfaction amongst a } \\
\text { large proportion of the } \\
\text { existing customer base. } \\
\text { Thousands of customers } \\
\text { with serious concerns. } \\
\text { Impact on essential } \\
\text { services for a short } \\
\text { duration. }\end{array}$ & $\begin{array}{l}\text { Region-wide customer } \\
\text { impact resulting in } \\
\text { significant } \\
\text { dissatisfaction amongst } \\
\text { more than } 100,000 \\
\text { customers. Major impact } \\
\text { on essential services for } \\
\text { a lengthy duration. }\end{array}$ \\
\hline
\end{tabular}

Table 3: Customer satisfaction consequence

$\begin{array}{ccc}\text { Minor } & \text { Moderate } & \text { Major } \\ <1 \% \text { of Gross Profit } & <3 \% \text { of Gross Profit } & <5 \% \text { of Gross Profit } \\ \text { or } & \text { or } & \text { or } \\ <\mathrm{R} 1 \mathrm{~m} & <\mathrm{R} 10 \mathrm{~m} & <\mathrm{R} 20 \mathrm{~m}\end{array}$

Table 4: Financial consequence

\subsection{The likelihood of the occurrence}

For simplicity and ease of use, three levels of likelihood - rare, possible, and almost certain - were chosen to indicate the probability of an occurrence of a specific consequence.

The criteria that will influence the likelihood of the consequence were identified as:

1. Historical failure rate: This relates to failures recorded via the Eskom NonConformance System (NCS). This will also take into account the number of problems experienced during manufacturing process inspections. The historical likelihood is given in Table 5.

2. Complexity of manufacturing: This category relates to the complexity of the manufacturing process as well as the skills required. It is influenced by the specifications and standards that must be adhered to. Stringent quality control is required by skilled people to ensure that complex products conform to specification. The complexity of manufacture likelihood is given in Table 6.

3. Safety margin: During the design process certain products are designed with a safety factor to cater for operation under high loads and abnormal circumstances - e.g. operating under high tension or in extreme weather conditions. The safety margin likelihood is given in Table 7. 


\section{Rare}

Possible

Almost certain

Isolated failures recorded Several failures recorded Frequent failures recorded

Table 5: Historical likelihood

$\begin{array}{ccc}\text { Rare } & \text { Possible } & \text { Almost certain } \\ \text { Basic specifications } & \text { Multiple specifications } & \text { Multiple complex } \\ \text { Basic process } & \text { Semi-complex processes } & \text { Multiple complex processes } \\ \text { Sample checking } & \text { Sample testing } & \text { All products tested } \\ \text { Unskilled labour } & \text { Semi-skilled labour } & \text { Professional skills required }\end{array}$

Table 6: Complexity of manufacture likelihood

\begin{tabular}{ccc}
\hline Rare & Possible & Almost certain \\
\hline $\begin{array}{c}\text { High }(3 \mathrm{x}) \text { safety margin } \\
\text { Product used under no } \\
\text { load }\end{array}$ & Medium $(1.5 \mathrm{x})$ safety & margin \\
& $\begin{array}{c}\text { Product used at medium } \\
\text { loads }\end{array}$ & Product used at high loads \\
\hline
\end{tabular}

Table 7: Safety margin likelihood

\subsection{Rating the risk level}

The risk consequence and the likelihood of occurrence were combined in a single matrix, as given Table 8. For simplicity, three risk levels -high, medium, and low were chosen.

By mapping the failure consequence as well as the likelihood of failure of different products on the risk matrix, the products could be categorised as high-, medium-. or low-risk products; and, according to these categories, different acquisition policies could be applied.

\section{RISK CATEGORISATION APPLICATION}

\subsection{The categorisation process}

The product categorisation process can be summarized sequentially as follows:

- $\quad$ Obtain details about the different products in use. This was done by studying Eskom's buyers' guide as well as other relevant documents including specifications and test details that are related to the specific product.

- $\quad$ Determine information about the possible failure consequence as well as a likelihood of failure. This is done by compiling and distributing a questionnaire to technical people to assess the products as well as the consequence and likelihood of failure. 
- $\quad$ Obtain the risk rating by mapping the consequence as well as the likelihood of failure on the Risk Matrix.

- $\quad$ Define a risk treatment option for the specific product.

\begin{tabular}{|c|c|c|c|c|c|c|c|}
\hline & & & & & \multicolumn{3}{|c|}{ Consequence } \\
\hline & & & & Safety & 5 & 10 & 15 \\
\hline & & & & 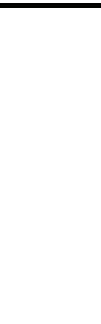 & $\begin{array}{c}\text { Some } \\
\text { customers } \\
\text { disconnected, } \\
\text { localized to a } \\
\text { small } \\
\text { geographic } \\
\text { area and fewer } \\
\text { than } 100 \\
\text { customers }\end{array}$ & $\begin{array}{c}\text { Dissatisfaction } \\
\text { amongst a } \\
\text { large number } \\
\text { of the existing } \\
\text { customer base. } \\
\text { Thousands of } \\
\text { customers } \\
\text { with serious } \\
\text { concerns. } \\
\text { Impact to } \\
\text { essential } \\
\text { services for a } \\
\text { short duration }\end{array}$ & $\begin{array}{c}\text { Region-wide } \\
\text { customer } \\
\text { impact } \\
\text { resulting in } \\
\text { massive } \\
\text { dissatisfaction } \\
\text { amongst more } \\
\text { than } 100,000 \\
\text { customers. } \\
\text { Major impact } \\
\text { to essential } \\
\text { services for a } \\
\text { long duration }\end{array}$ \\
\hline & & & & $\begin{array}{c}\text { Customer } \\
\text { satisfaction }\end{array}$ & & & \\
\hline & & & & 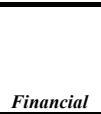 & $\begin{array}{c}<1 \% \text { of Gross } \\
\text { Profit } \\
\text { or } \\
<\mathrm{R} 1 \mathrm{~m} \\
\end{array}$ & $\begin{array}{c}<3 \% \text { of Gross } \\
\text { Profit } \\
\text { or } \\
<\mathrm{R} 10 \mathrm{~m}\end{array}$ & $\begin{array}{c}<5 \% \text { of Gross } \\
\text { Profit } \\
\text { or } \\
<\mathrm{R} 20 \mathrm{~m}\end{array}$ \\
\hline & $\begin{array}{c}\text { Complexity } \\
\text { of } \\
\text { manufacture }\end{array}$ & Historical & $\begin{array}{c}\text { Safety } \\
\text { margin }\end{array}$ & & Minor & Moderate & Major \\
\hline & $\begin{array}{c}\text { Multiple } \\
\text { complex } \\
\text { specifications. } \\
\text { Multiple } \\
\text { complex } \\
\text { processes. All } \\
\text { products } \\
\text { tested. } \\
\text { Professional } \\
\text { skills required }\end{array}$ & $\begin{array}{l}\text { Frequent } \\
\text { failures } \\
\text { recorded }\end{array}$ & $\begin{array}{c}\text { No safety } \\
\text { margin. } \\
\text { Product used } \\
\text { under high } \\
\text { loads }\end{array}$ & $\begin{array}{l}\text { Almost } \\
\text { certain }\end{array}$ & Medium & High & High \\
\hline & $\begin{array}{c}\text { Multiple } \\
\text { specifications. } \\
\text { Semi- } \\
\text { complex } \\
\text { processes. } \\
\text { Sample } \\
\text { testing. Semi- } \\
\text { skilled labour }\end{array}$ & $\begin{array}{l}\text { Several } \\
\text { failures } \\
\text { recorded }\end{array}$ & $\begin{array}{c}\text { Medium } \\
(1.5 \mathrm{x}) \text { safety } \\
\text { margin. } \\
\text { Product used } \\
\text { under medium } \\
\text { loads }\end{array}$ & Possible & Low & Medium & High \\
\hline 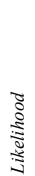 & $\begin{array}{c}\text { Basic } \\
\text { specifications. } \\
\text { Basic process. } \\
\text { Sample } \\
\text { checking. } \\
\text { Unskilled } \\
\text { labour }\end{array}$ & $\begin{array}{l}\text { Isolated } \\
\text { failures } \\
\text { recorded }\end{array}$ & $\begin{array}{c}\text { High }(3 \mathrm{x}) \\
\text { safety margin. } \\
\text { Product used } \\
\text { under no load }\end{array}$ & Rare & Low & Low & Medium \\
\hline
\end{tabular}

Table 8: Risk matrix 


\subsection{A risk categorisation example}

For the purpose of this study, a number of randomly selected products were used. The above-mentioned risk categorisation process was followed to obtain the product information consequence, as well as the likelihood of failure, by means of a product questionnaire. The information for a $22 \mathrm{kV}$ line post insulator is given in Error! Reference source not found.. The risk rating was then established, using the defined Risk Matrix. The risk rating is given in Table 9.

\section{RISK EVALUATION AND MITIGATION PROPOSALS}

The aim of risk evaluation and mitigation is to limit the product risk. The risk can not be tolerated and must be dealt with. After a product has been categorised and a risk level has been assigned to it, it is necessary to select an appropriate mitigation strategy for the product. Since the investigation of a mitigation strategy for individual products did not form part of this research, the following treatment is proposed.

\subsection{Design risk}

- $\quad$ Approve designs by independent designers

- Include more detail in the design

- $\quad$ Give more detailed specifications

- $\quad$ Carry out physical tests prior to approval

\subsection{Manufacturing risk}

The highest risk is currently in the manufacturing process, where it is possible to treat risk to a large extent. There are various methods to minimize the manufacturing risk, such as:

- Institute a more stringent approval system for manufacturers

- $\quad$ Limit the number of manufacturing plants, and increase control

- Increase the frequency of independent inspections of manufacturing plants

- $\quad$ Enforce adherence to quality systems - e.g.

- High risk - require ISO certification or SABS marked system

- Medium risk - document processes in accordance to ISO system

o Low risk - follow Eskom system requirements

$\begin{gathered}\text { Product : Insulator, Line Post } 22 \mathrm{kV} 10 \mathrm{kN} \\ 31 \mathrm{~mm} / \mathrm{kV}\end{gathered}$
PAP No : $0168049 \quad$ DDT No : D DT 3017
Short Description: Line post insulator (cap less) * for heavy and very heavy
pollution areas * rated voltage $22 \mathrm{kV}$ * specific creepage $31 \mathrm{~mm} / \mathrm{kV}$ * cantilever
strength $10 \mathrm{kN}$ * lighting impulse withstand $170 \mathrm{kV}$ * rated $50 \mathrm{hz}$ wet withstand
$50 \mathrm{kV}$ *F-neck * insert M20x2.5-6h $(0.38 \mathrm{~mm}$ oversize) * $55 \mathrm{~mm}$ thread depth *
spindle D-DT-3050 for use up to kingbird conductor * line post insulators to be
approved by insulator work group * insulator to be light grey in colour for $10 \mathrm{kN}$




\section{post insulators}

Applicable Standards: Failing load (kn): 4kIN AND 10kN MINIMUM. Creepage distance $(\mathrm{mm}): 20 \mathrm{~mm} / \mathrm{kV}$ \& $31 \mathrm{~mm} / \mathrm{kV}$. Standard specification: F-NECK. Eskom specification: SCSSCABI8

Test requirements: Type test at min failing load and certificate each item to be routine tested to $60 \%$ min failing load

\begin{tabular}{|c|c|c|c|c|}
\hline Safety & \multicolumn{3}{|c|}{ Rating } & Score \\
\hline Question & 1 & 2 & 3 & \\
\hline $\begin{array}{l}\text { What is the } \\
\text { population density } \\
\text { where the product } \\
\text { is used? }\end{array}$ & $\begin{array}{l}\text { Unpopulated } \\
\text { rural }\end{array}$ & $\begin{array}{c}\text { Unpopulated and } \\
\text { populated rural }\end{array}$ & $\begin{array}{l}\text { Populated } \\
\text { rural }\end{array}$ & 2 \\
\hline $\begin{array}{l}\text { If the product } \\
\text { fails, will it create } \\
\text { a situation that } \\
\text { live conductors } \\
\text { will be in close } \\
\text { proximity to } \\
\text { people? }\end{array}$ & No & Sometimes & Yes & 3 \\
\hline $\begin{array}{l}\text { Do systems exist } \\
\text { to ensure that the } \\
\text { dangerous } \\
\text { situation cannot } \\
\text { exist for an } \\
\text { extended period }\end{array}$ & $\begin{array}{l}\text { Protection } \\
\text { will always } \\
\text { clear the } \\
\text { fault }\end{array}$ & $\begin{array}{l}\text { Protection will } \\
\text { sometimes clear } \\
\text { the fault }\end{array}$ & $\begin{array}{c}\text { The chance } \\
\text { that } \\
\text { protection } \\
\text { will clear } \\
\text { the fault is } \\
\text { low }\end{array}$ & 2 \\
\hline $\begin{array}{l}\text { Seriousness of } \\
\text { injury }\end{array}$ & Minor & Serious & Death & 3 \\
\hline \multirow[t]{2}{*}{ Treatment } & First Aid & \multirow[t]{2}{*}{ Hospitalization } & $\begin{array}{l}\text { Death (No } \\
\text { treatment) }\end{array}$ & 3 \\
\hline & & & TOTAL: & 13 \\
\hline $\begin{array}{l}\text { Impact or } \\
\text { Consequence }\end{array}$ & Minor & Moderate & Major & $\begin{array}{c}\text { Rating } \\
\text { (Mi, Mo, } \\
\text { Ma) }\end{array}$ \\
\hline Safety & $0-6$ & $7-11$ & $12-15$ & $\mathrm{Ma}$ \\
\hline $\begin{array}{l}\text { How many } \\
\text { customers will } \\
\text { be affected if } \\
\text { the product } \\
\text { fails }\end{array}$ & $\begin{array}{l}\text { Some } \\
\text { customers } \\
\text { disconnected, } \\
\text { localized to a } \\
\text { small } \\
\text { geographic } \\
\text { area and less } \\
\text { than } 100\end{array}$ & $\begin{array}{l}\text { Dissatisfaction } \\
\text { amongst a } \\
\text { large number } \\
\text { of the existing } \\
\text { customer } \\
\text { base, } \\
\text { thousands of } \\
\text { customers }\end{array}$ & $\begin{array}{l}\text { Region wide } \\
\text { customer } \\
\text { impact } \\
\text { resulting in } \\
\text { massive } \\
\text { dissatisfaction } \\
\text { amongst more } \\
\text { than } 100000\end{array}$ & $\mathrm{Ma}$ \\
\hline
\end{tabular}




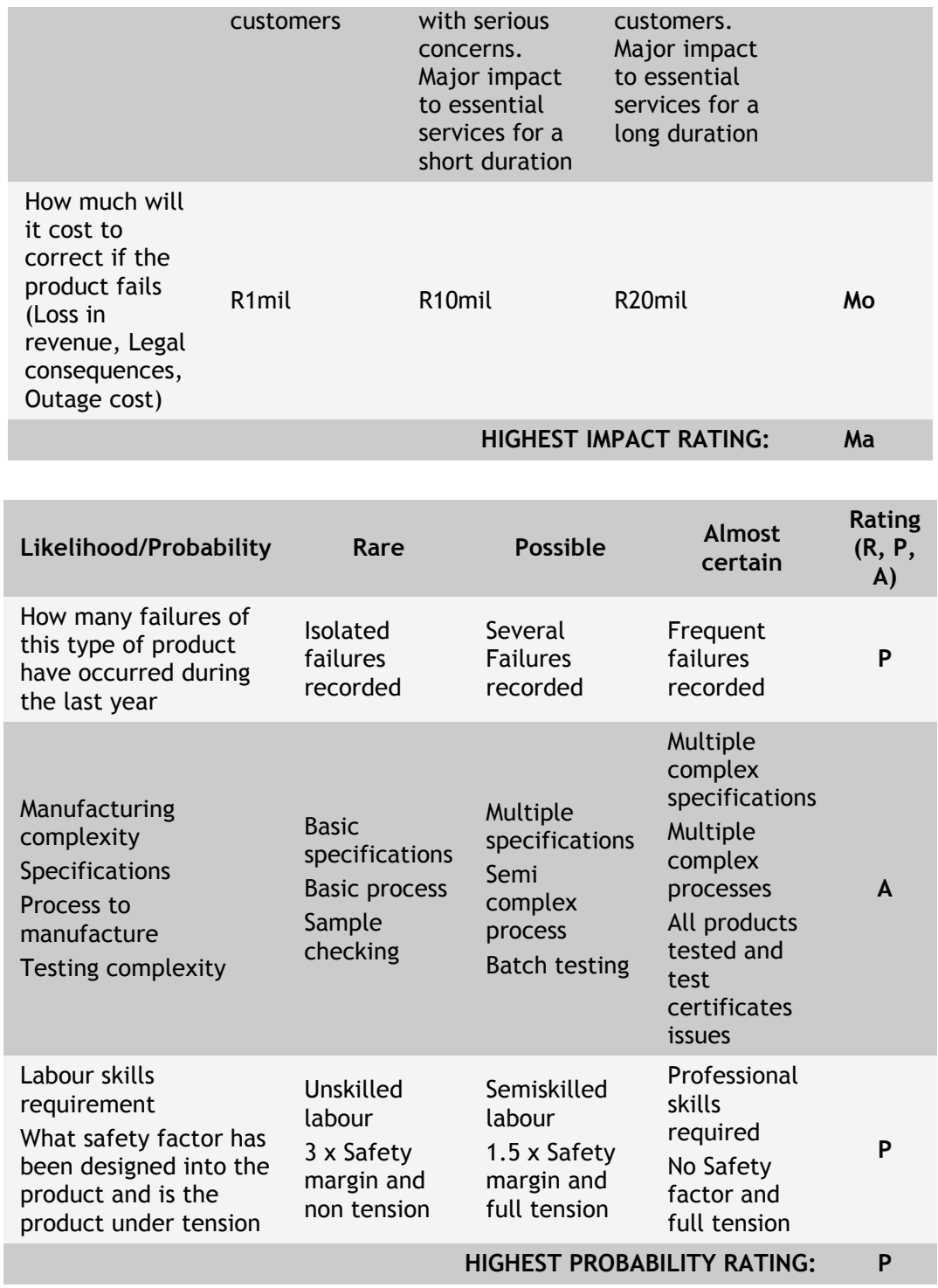

Table 9: Risk categorisation example: Product information questionnaire 


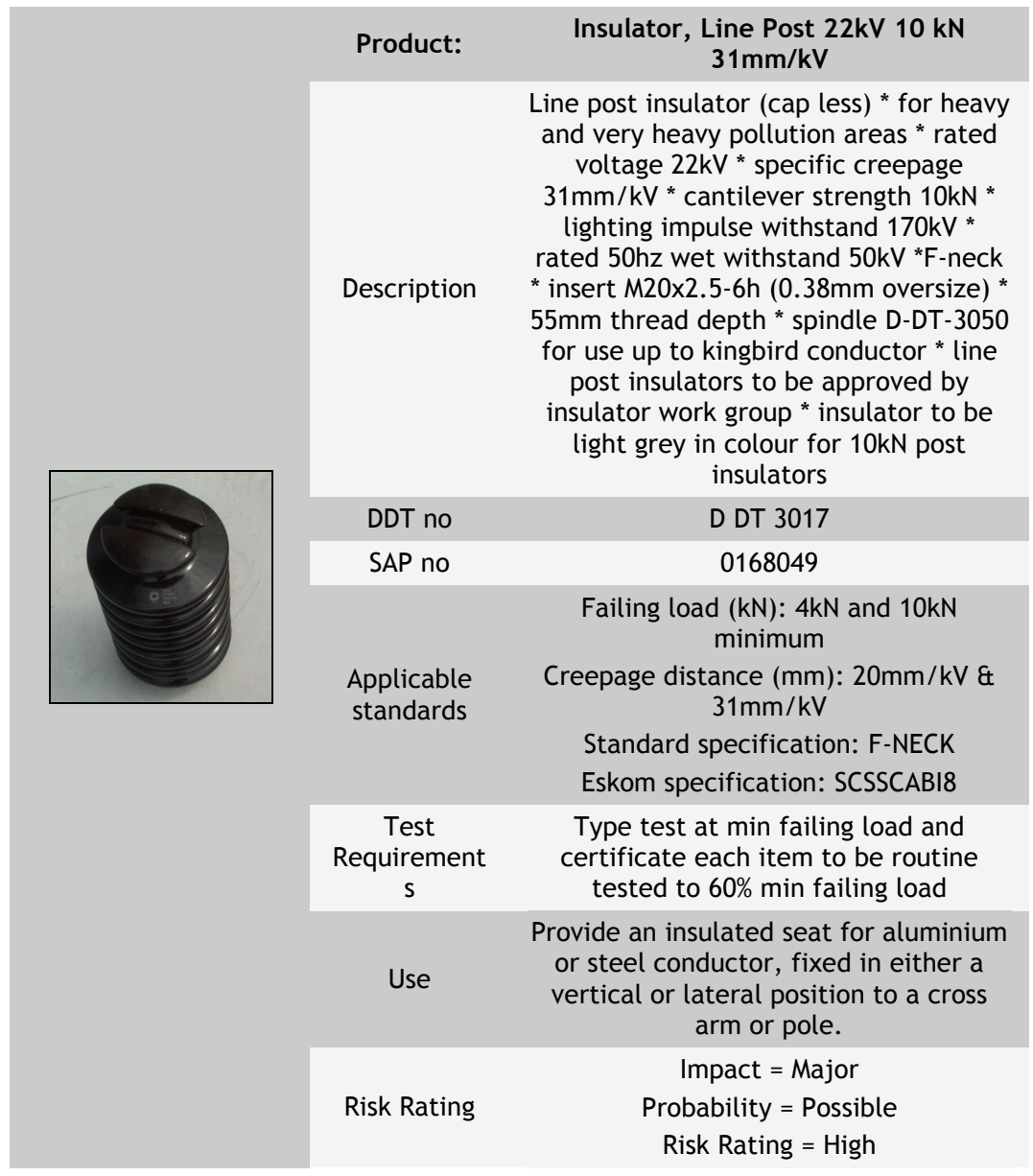

Table 10: Risk categorisation example: Risk rating 


\subsection{Installation risk}

- Document installation criteria

- Train personnel

- $\quad$ Accredit installers

\subsection{Maintenance risk}

- $\quad$ Document maintenance criteria

- Train personnel

- $\quad$ Accredit maintenance personnel

\section{CONCLUSION}

A risk categorisation model was developed and tested for a sample of products. Although not shown in this paper, the results from skilled and semi-skilled technical people were very similar. Evaluation took an average of three minutes per product. This is an indication that this simple model is easy to understand and use. Some products were also identified that required more stringent control, contrary to previous manufacturing and purchasing methods.

The company is currently in the process of categorising all the products used to construct electrical networks. An improvement in quality and reduced nonconformance will only be seen over time, after the implementation of risk treatment methods.

A slight increase in product prices can be expected initially, owing to the implementation of more stringent quality management systems in the manufacturing process. Auditing methods will also have to be identified to deal with products manufactured overseas. The model is not completely quantitative, and perceptions and historical knowledge can cause variations to affect the outcome.

In future slight adjustments to the questionnaire will be implemented to improve the model. Owing to the large quantity of products, the initial evaluation of the products is time-consuming, and the possibility of grouping products will be investigated.

\section{REFERENCES}

[1] Reuvid, J., (2005). Managing business risk. A practical guide to protecting your business ( $2^{\text {nd }}$ edition). Kogan Page and Contributors, Great Britain and the United States of America.

[2] Engert, P.E., Lansdowne, Z.F., (Nov 1999). Risk matrix user's guide, Version 2.2, Document no. MP99B0000029, The MITRE Corporation. Available: http://www.mitre.org.

[3] Smith, S.B., Tiolet, P.L. Practical product component risk analysis and management, Optics Purchasing Alcatel, Institute of Supply Management, United Kingdom and France. Available: http://www.ism.ws 
[4] Australian Capital Territory Insurance Authority (ACTIA), (Feb 2004). Risk management toolkit. Available: http://www.treasury.act.gov.au

[5] National Minerals Industry (NMI), (Jan 2004). Safety and health risk assessment guideline, Version 4, University of Queensland, Australia. Available: http://www.mishc.uq.edu.au 
http://sajie.journals.ac.za 